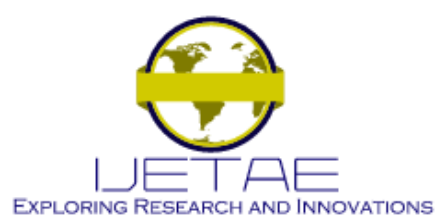

International Journal of Emerging Technology and Advanced Engineering

Website: www.ijetae.com (ISSN 2250-2459, ISO 9001:2008 Certified Journal, Volume 3, Issue 8, August 2013)

\title{
Responsible Supply Chain
}

\author{
Vivek Gedam $^{1}$, M.Krishna ${ }^{2}$, Saurab Jain ${ }^{3}$, P.K.Sahu ${ }^{4}$, Sandeep Dubey ${ }^{5}$ \\ ${ }_{1,3,4,5}$ Asst. Professor, ${ }^{2}$ Professor, G.G.I.T.S., Jbp
}

\begin{abstract}
Multinational companies are increasing their focus on supply chain as a strategic factor. They are indulged with a vast number of social, environmental and ethical standards in their supply chain. But despite the efforts at their monitoring, buyers routinely face challenges when working with suppliers to meet and exceed standards, in a recent survey it is found that over $\mathbf{8 0 \%}$ of the $\mathbf{7 5 0}$ firms polled have Social and environmental monitoring systems for their internal operations, but that less than a third have such systems in their immediate and extended supplier network. Responsible supply chain relates to the degree of formality and comprehensiveness of business practices. Developing a better understanding of this relationship will strengthen the case for integrating RSC practices with traditional supply chain management practices and can help identify RSC practices that build social, environmental, and economic value.
\end{abstract}

Keywords-- supply chain sustainability, RSC Management, Corporate Sustainability Assessment, Corporate responsibility Initiative.

\section{INTRODUCTION}

In recent years, companies have faced increasing challenges in their ability to manage their supply chains. Long and complex supply chains are significant parts of our global business life as a result of vertical disintegration, product proliferation, focus on core activities, multichannel set ups and global sourcing (Balasubramanian and Tewary, 2005). According to an executive, "The purchasing power of a corporation can become a unique driver for bringing about positive change in society. Companies must use this power to achieve a purpose and make their supply chain a vehicle for inclusive growth" (Baldwin, A. - Strandberg, C. (2010)). In order to achieve this purpose companies need to manage their supply chains in a responsible way.

1.1 Responsible Supply Chain Management as a Vital Component of Corporate Social, Environmental and Ethical Standards Responsibility:

Responsible Supply Chain Management (RSCM) embodies an interaction between Corporate Social Responsibility (CSR) and Supply Chain Management (SCM).
A practical guide for continuous improvement of Supply Chain Sustainability emphasis that "more and more companies are extending their commitment to responsible business practices to their value chains, from subsidiaries to suppliers" and introduces supply chain sustainability as a key component of corporate responsibility (Baldwin, A. Strandberg, C. (2010). Several articles have been written over the years that examine various aspects of Responsible Supply Chain Management. There are different terms regarding this issue with similar content. Most aspects of RSC management (e.g., non-discrimination policies, worker health and safety management, emissions reduction, anti-corruption measures) can be associated with one of three broad categories: social responsibility, environmental sustainability, and ethical integrity.

\subsection{Definition of Responsible Supply Chain Management (RSCM):}

Responsible Supply Chain Management (RSCM) emerged in the 1990s as a corporate response to human rights violations (e.g. sweat shops, child labour, forced labour, no living wage, discrimination and safety and health neglect) appearing in the supply chain (Carroll, A. B. (1979)). According to the International Chamber of Commerce (2007, p. 2), "Supply chain responsibility, also referred to as responsible sourcing, can be broadly defined as a voluntary commitment by companies to manage their relationships with suppliers in a responsible way. As a result of their purchasing activities, companies may have some opportunities to influence constructively their suppliers' social and environmental performance. This can be done using several incentives, including information and training, as well as audits of suppliers' practices. Whatever mechanism is used, the most effective way to achieve sustained improvement over time is through the development of a long-term collaborative relation between corporate buyers and their suppliers, through which suppliers can internalize change by participating in the shaping of social and environmental performance objectives, based on their own perception of their business capacity and needs."(Cooper, M. C. - Lambert, D. M. Pagh, J. D. (1997) 


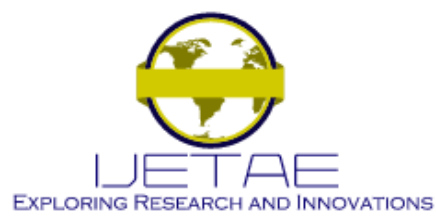

\section{International Journal of Emerging Technology and Advanced Engineering}

\section{Website: www.ijetae.com (ISSN 2250-2459, ISO 9001:2008 Certified Journal, Volume 3, Issue 8, August 2013)}

The United Nations Global Compact (2010) refers to supply chain sustainability and defines this as "the management of environmental, social and economic impacts and the encouragement of good governance practices, throughout the lifecycles of goods and services.
The objective of supply chain sustainability is to create, protect and grow long-term environmental, social and economic value for all stakeholders involved in bringing products and serves to markets."( Closs, D. J., Speierm C. \& Meacham, N. (2011)

Table 1

Advantages of Responsible Supply Chain Management:

\begin{tabular}{|c|c|}
\hline CONCERNED ISSUES & PURPOSE FULLFILLMENT \\
\hline 1) Create sustainable products & $\begin{array}{l}\text { Meeting evolving customer and business partner requirements and } \\
\text { innovating for a changing market. }\end{array}$ \\
\hline 2) Increase legitimacy among stakeholders & $\begin{array}{l}\text { Implementing CSR standard in supply chains has a positive impact on } \\
\text { ensuring legitimacy among supply chain partners as well as towards } \\
\text { other stakeholders. }\end{array}$ \\
\hline $\begin{array}{l}\text { 3) Protect the company's reputation and brand } \\
\text { value }\end{array}$ & $\begin{array}{l}\text { Reputation is a very sensitive asset of companies. } \\
\text { Reputation problems can cause competitive disadvantages, as has } \\
\text { happened in the past in the case of some companies. }\end{array}$ \\
\hline 4) Minimize risks & $\begin{array}{l}\text { RSCM provides the possibility to avoid social and environmental } \\
\text { problems in pre-stages, bringing } \\
\text { new criteria into supplier evaluation and monitoring. }\end{array}$ \\
\hline 5) Business benefits & $\begin{array}{l}\text { In the supply chain system responsibility can increase profit through } \\
\text { significant operational efficiency gains, reducing global waste and the } \\
\text { cost of material inputs, energy, and transportation. }\end{array}$ \\
\hline 6) Enhancement of people and their communities & $\begin{array}{l}\text { Commitment to acceptable global working conditions and compliance } \\
\text { with regulatory requirements. }\end{array}$ \\
\hline $\begin{array}{l}\text { 7) Minimize reliance on scarce environmental } \\
\text { resources }\end{array}$ & $\begin{array}{l}\text { While minimizing waste of water or raw materials, } \\
\text { ensuring long-term global viability. }\end{array}$ \\
\hline 8) Improve supplier performance & $\begin{array}{l}\text { This helps to build increased commitment and trust in the } \\
\text { buyer/supplier relationship that can lead to increased labor productivity } \\
\text { or creating efficiency across supply chains, or directly to improved } \\
\text { levels of supplier performance. }\end{array}$ \\
\hline 9) Competitive advantage & $\begin{array}{l}\text { If RSCM is not simply window dressing but can provide the } \\
\text { organization with both tangible and direct benefits, which may } \\
\text { ultimately lead to a competitive advantage for their firms. }\end{array}$ \\
\hline 10) Positive environmental impact & Companies protect the environment. \\
\hline 11) Positive social impact & $\begin{array}{l}\text { Companies can promote human rights, improve labor conditions and } \\
\text { support ethical business conduct. }\end{array}$ \\
\hline 12) Efficiency and profitability over the long term & $\begin{array}{l}\text { Focusing on economic, social and environmental performance (profit, } \\
\text { people, and planet) will lead to improved efficiency and profitability } \\
\text { over the long term. }\end{array}$ \\
\hline 13) Support further economic development & $\begin{array}{l}\text { Economic development has secondary impacts on socioeconomic } \\
\text { development and the environment and is therefore a critically } \\
\text { important aspect of sustainability. }\end{array}$ \\
\hline
\end{tabular}

\subsection{Research Questions}

1) What supplychain practices do buyers (i.e., purchasers of materials and services): Employ that they believe have a positive impact on social, environmental, and ethical performance?

2) Can we develop a framework to assess the relationship between maturity in RSC Practices and supply chain performance?

\section{Methodology}

Ensuring the resilience, efficiency and agility of supply chains, combined with the need to demonstrate responsible supply chain practices, pose important challenges to today's businesses. The source of a product, production methods, packaging, safety, carbon footprint and ethical performance are some of the issues that consumers are increasingly concerned about and which influence their purchasing decisions. 


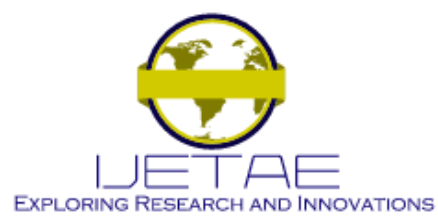

\section{International Journal of Emerging Technology and Advanced Engineering}

\section{Website: www.ijetae.com (ISSN 2250-2459, ISO 9001:2008 Certified Journal, Volume 3, Issue 8, August 2013)}

Increasing consumer awareness, combined with greater visibility of the impacts of a product at different stages in its lifecycle, pose interesting risks and opportunities. As a result, managing risk has become essential to the success of all businesses operating along the supply chain, from farmers, fishermen and growers to food processors, retailers, distributors, and storage and transport companies Most aspects of RSC management (e.g., non-discrimination policies, worker health and safety management, emissions reduction, anti-corruption measures) can be associated with one of three broad categories: social responsibility, environmental sustainability, and ethical integrity.

UN Global Compact is the world's greatest voluntary corporate responsibility initiative, which provides ten principles based on categories including human rights, labor, environment, and anti-corruption. These ten principles act like guide for RSC

\section{Human Rights:}

Principle 1: Businesses should support and respect the protection of internationally proclaimed human rights.

Principle 2: Businesses should make sure that they are not complicit in human rights abuses.

\section{B) Labour Standards:}

Principle 3: Businesses should uphold the freedom of association and the effective recognition of the right to collective bargaining;

Principle 4: Businesses should uphold the elimination of all forms of forced and compulsory labour;
Principle 5: Businesses should uphold the effective abolition of child labour; and

Principle 6: Businesses should uphold the elimination of discrimination in respect of employment and occupation.

\section{C) Environment}

Principle 7: Businesses should support a precautionary approach to environmental challenges;

Principle 8: Businesses should undertake initiatives to promote greater environmental responsibility; and

Principle 9: Businesses should encourage the development and diffusion of environmentally friendly technologies.

\section{D) Anti-Corruption}

Principle 10: Businesses should work against corruption in all its forms, including extortion and bribery.

\subsection{Findings:}

A company's behavior in terms of social and environmental responsibility is now central to its reputation. Detailed scrutiny of those practices by a range of stakeholders - by nongovernmental organizations (NGOs) and the media as well as customers and investors - is also holding businesses to task for the practices of their supplier and their suppliers' suppliers. Yet it is not easy for businesses to assess whether those suppliers, are following UN global compact standards, especially as supply chains grow longer.

When UN global compact principles practices fall short, companies can face product disruption problems, legal difficulties and other business risks.

Table 2:

Code Of Conduct Prescribed For Industries:

\begin{tabular}{ll}
\hline \multicolumn{1}{c}{ TOPIC } & \multicolumn{1}{c}{ ELEMENTS OF CODE } \\
\hline LABOUR & Freely chosen employment, child labor avoidance, working hours. \\
MANAGEMENT SYSTEM & Risk management, training, communication, worker feedback and participation \\
HEALTH AND SAFETY & Occupational safety, emergency preparedness, machine safeguarding \\
ENVIRONMENT & Pollution prevention, hazardous substances, product content \\
ETHICS & No improper advantage, disclosure of information, community engagement. \\
\hline
\end{tabular}

\subsection{Four Phase Execution of Responsible Supply Chain:}

Four phase execution method consists of four basic steps: 1) Introduction, 2) Assessment, 3) Validation, 4) Continual Improvement. In the introduction phase preliminary risk assessment is being done also UN global compact standards are being confirmed in contract, where as in assessment phase complete self assessment and inter - departmental review and feed back is being done, validation is the process of corrective action plan that too if required, and at last continual improvement stresses on identifying key education areas, and help in building suppliers capability in key areas by building their skills, toolset and expertise required education areas, special skills training, capability increasing tools etc.( Handfield, R. B. Nichols, E. L. (1999) 


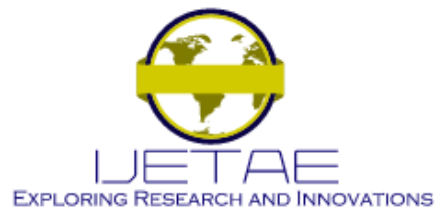

International Journal of Emerging Technology and Advanced Engineering Website: www.ijetae.com (ISSN 2250-2459, ISO 9001:2008 Certified Journal, Volume 3, Issue 8, August 2013)

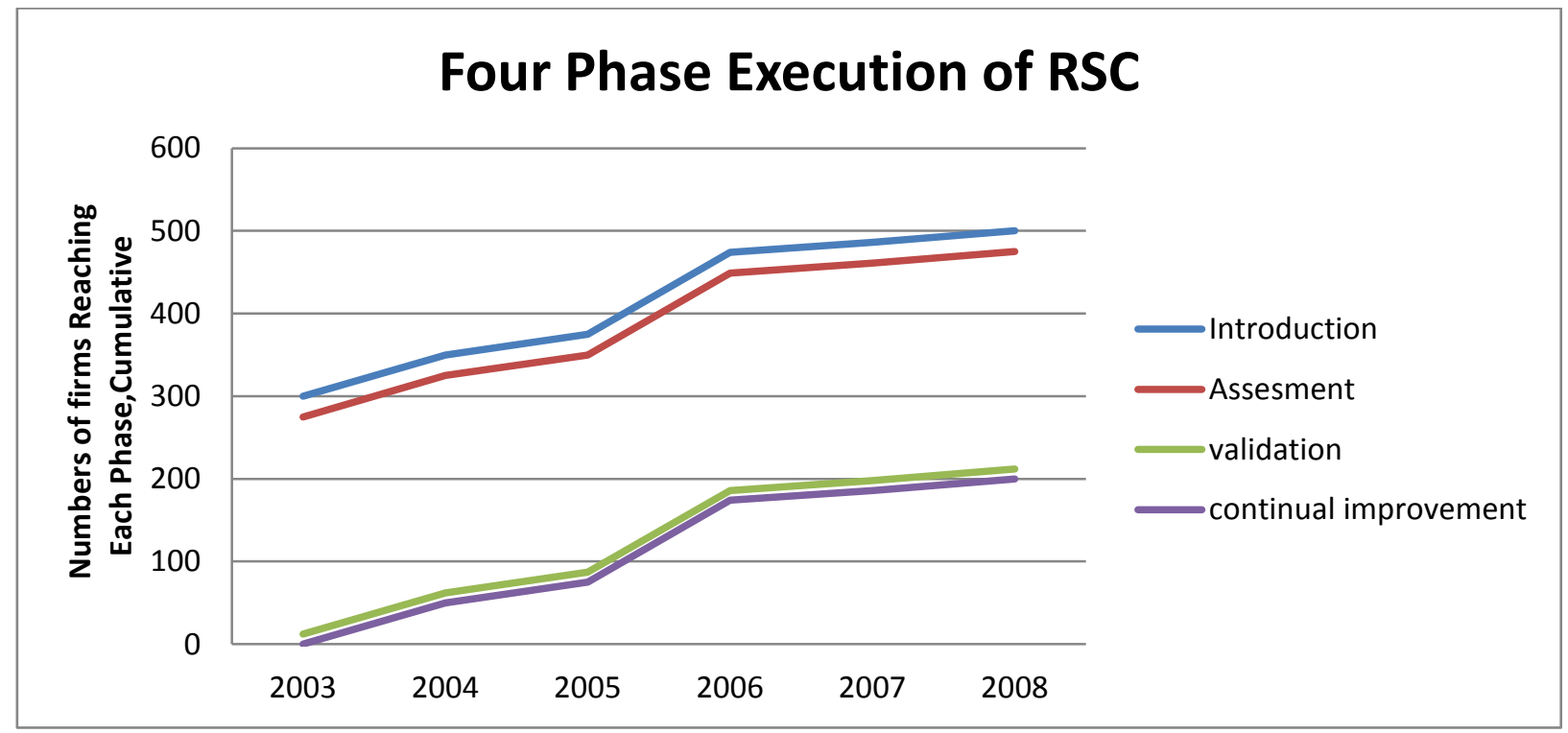

GRAPH 1: The gap between introduction and assessment represents sites that are low-risk based on the company or country they are in. The gap between assessment and validation represents sites whose self-assessments indicate they are low risk.

\subsection{Breakdowns in RSC Practices:}

Despite the fact that multinational corporations have been auditing their supply chains for years, significant problems of noncompliance (violations of industry codes of conduct or law, or both) still exist. In 2011, the Fair Labor Association found that $90 \%$ of factories audited in Asia had overtime violations. Apple received attention in early 2012 after The New York Times reported on explosions and excessive working hours at Foxconn, a subcontract manufacturer to Apple and other electronics companies with operations in China. In China, as much as $70 \%$ of the rivers, lakes, and reservoirs are affected by water pollution; hazardous materials used by factories in industries such as apparel and electronics contribute to this pollution. (Handfield, R. B. - Nichols, E. L. (1999)

Intellectual property theft is a huge and growing challenge, costing businesses across the world around \$1trillion annually in lost sales. A 2009-2010 investigation by the US Senate Armed Services Committee uncovered 1,800 cases of suspected counterfeit electronic components in contracts with defense companies such as Raytheon, Boeing, and Lockheed Martin.

\subsection{Causes of Breakdowns}

Breakdowns in RSC practices are complex and influenced by various internal and external forces. Suppliers may not have the leadership, capability, or training needed to comply with requirements. On the buyer side, if a buyer is a major customer of a supplier, the buyer may have more power to promote responsible practices at the supplier. On the other hand, this leverage can result in negative consequences. For example, when a buyer has the power to push through large or late orders or demand short lead-time on an order, the supplier may respond by pushing its work force to work longer hours than allowed. Other causes of breakdowns include: lack of regulation, lack of enforcement or penalties, non-standardized regulation across and with in countries, and regional or cultural factors (e.g., workers in China may desire to work more hours, hence making working hour compliance more challenging). Finally, given the limited evidence showing a correlation between RSC practices and supply chain performance, buyers may not be sufficiently motivated to invest in these practices. 


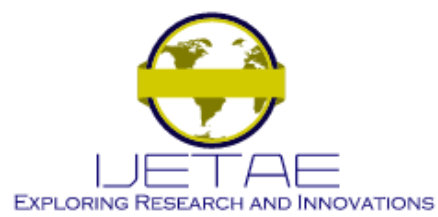

International Journal of Emerging Technology and Advanced Engineering

Website: www.ijetae.com (ISSN 2250-2459, ISO 9001:2008 Certified Journal, Volume 3, Issue 8, August 2013)

\section{ELEMENTS OF RESPONSIBLE SUPPLy CHAIN MANAGEMENT}

The sustainability benchmarking provides practical information regarding Responsible Supply Chain Management. SAM Corporate Sustainability Assessment compares corporate sustainability performance of more than 2,000 companies. The Dow Jones Sustainability World Index (DJSI) was launched in 1999 as the first global sustainability benchmark and provides an effective engagement platform for companies who want to adopt sustainable best practices. As of 2012 SAM offers detailed reports of the so-called 19 super sector leaders (Linton, J. D., - Klassen, R. - Jayaraman, V. (2007)

According to these reports ten of the super sector leaders have an excellent performance in Supply Chain Management as well. Table 2 shows the score of the super sector leaders, DJSI average scores and the score of the best company within sectors. The reports contain several best practices in Supply Chain Management as well. Unilever extended sustainability to its raw material sourcing practices, and transparency along the whole supply chain plays an important role.
Repsol introduced a comprehensive supply management process to track its suppliers' performance. The supply chain management of Koninklijke Philips Electronics N.V. fully integrates Environmental, Social and Corporate Governance criteria to identify key supply chain risks and the company collaborates with suppliers to resolve the problems. Supply Chain Management of Siemens focuses on the potential human rights abuses among further factors (Linton, J. D.,- Klassen, R.- Jayaraman, V. (2007)

Based on the websites of super sector leaders the main elements of Responsible Supply Chain Management are shown in (Table 3). Most of the companies set special standards for their suppliers in a form of Code of Conduct, sustainability standard or supplier declaration. Companies offer workshops and training courses for their suppliers in order to make them familiar with the required norms. Further common elements of the Responsible Supply Chain Management are a supplier self assessment and supplier audit, which can be internal or external. Some of the studied companies have dialogues with their suppliers and implement special awards to improve the CSR performance of their suppliers. (Linton, J. D., - Klassen, R. - Jayaraman, V. (2007)

Table 3:

Elements of Responsible Supply Chain Management:

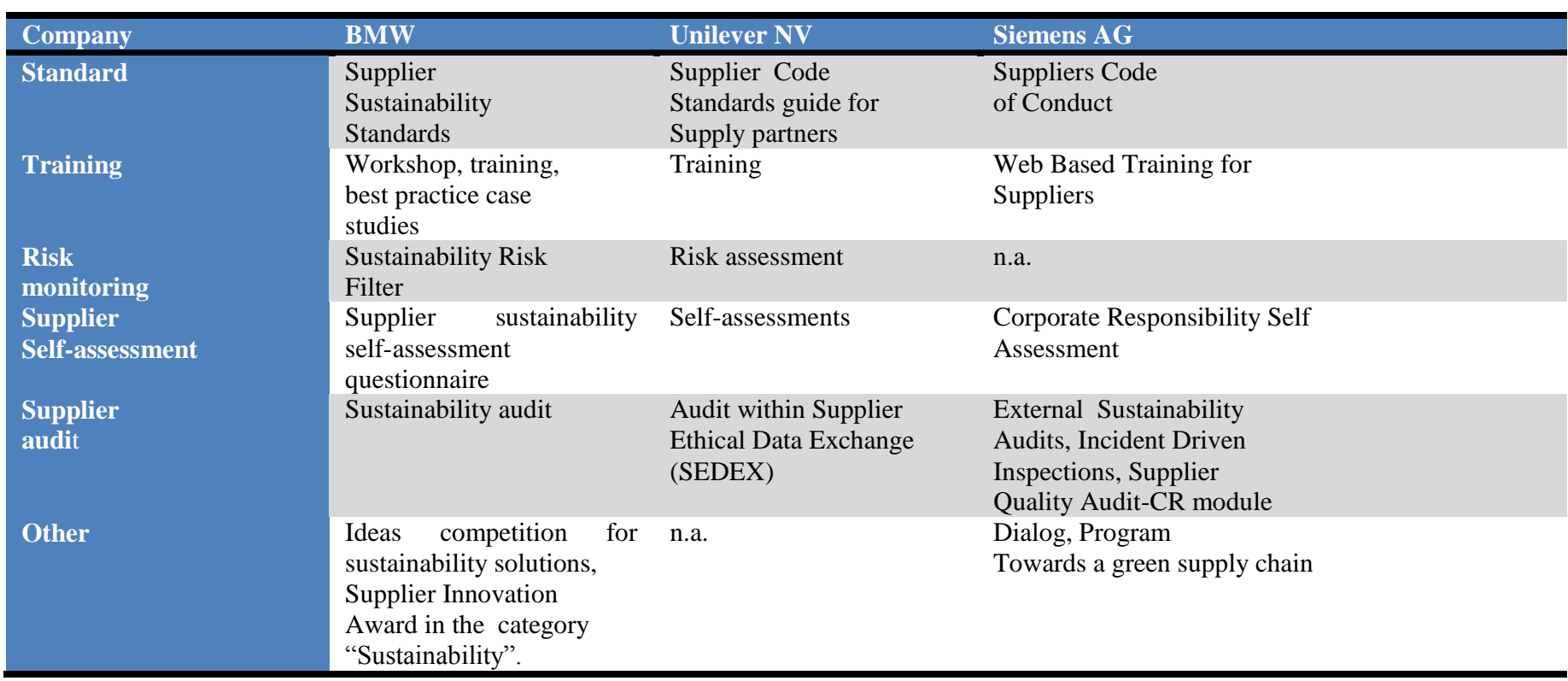

\subsection{Better Practices:}

According to CSR Europe the companies of HP, Titan and Volkswagen play a leading role in the European CSR Laboratory on Responsible Supply Chain Management.
The Portal for Responsible Supply Chain Management contains information for practitioners to further develop their own approach to Corporate Social Responsibility in the Supply Chain (CSR Europe, 2008). 


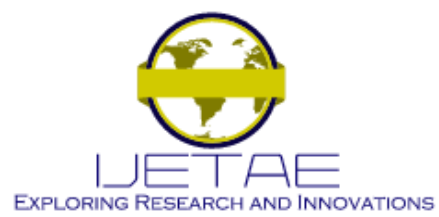

\section{International Journal of Emerging Technology and Advanced Engineering Website: www.ijetae.com (ISSN 2250-2459, ISO 9001:2008 Certified Journal, Volume 3, Issue 8, August 2013)}

Based on GRI reports of these companies we have summarized some important characteristics of their supply chain management.

\subsection{Hewlett-Packard Company (HP, 2011)}

The company is an American multinational hardware and software corporation headquartered in Palo Alto, California, United States. It provides products, technologies, software, solutions and services to consumers, small and medium-sized businesses (SMBs) and large enterprises, including customers in the government, health and education sectors. Tools in use are external and internal audits. HP makes sure third-party auditors regularly verify its global Greenhouse gas (GHG) emissions measurements and annual reporting under the GHG measurement and reporting protocols of the World Resources Institute and World Economic Forum. Further product reuse and recycling is regularly monitored by thirdparty auditing firms, and 14 reuse and 39 recycling vendor facilities were assessed in 24 countries in 2011. In addition, HP's supply chain responsibility ensures that external audit firms conduct necessary verification of suppliers' self assessments. On the field of HSE the company is regularly assessed by independent accredited auditors according to ISO 14001 and Occupational Health and Safety Assessment Series (OHSAS) 18001.As a self-regulatory function qualified HP professionals conduct internal audits of the environmental, health, and safety management systems at its operation sites, and they report the results to senior management. Compliance and ethics, privacy, and environment, health, and safety may be evaluated, depending on the nature of the operation being audited. (Worthington, I. - Ram, M. - Boyal, H. - Shah, M. (2008)

HP is a signatory to the United Nations Global Compact, a set of voluntary commitments for companies to improve human rights, labor conditions, the environment, and anticorruption controls. HP implemented Global Reporting Initiative to enhance the quality and transparency of their reporting on CSR topics. HP self-declares this report to GRI Application Level B. (WCED (1987)

\subsection{Titan (WBCSD Cement Sustainability Initiative, 2011)}

Titan Cement Company S.A. is one of the world's eight largest cement producing companies, based in the Ano Patissia suburb of Athens, Greece.
In 1999 a group of leading cement companies came together and created the Cement Sustainability Initiative (CSI), under the auspices of the World Business Council for Sustainable Development (WBCSD). This is a voluntary, continuous improvement approach focused on making the cement industry and business in general, more sustainable. The main issues of the initiative are Climate Protection, Fuels and Materials, Health \& Safety, Emissions Reduction, Biodiversity, Sustainability with concrete KPIs: The Getting the Numbers Right (GNR) system is a sector-wide global information database that provides accurate, verified data on the cement industry's $\mathrm{CO} 2$ emissions and energy performance like Specific heat consumption of clinker production; Alternative Fuel Rate; Biomass Fuel Rate; Alternative Raw Materials Rate; and Clinker/Cement Ratio

\subsection{Volkswagen (Volkswagen, 2011)}

Volkswagen (abbreviated VW) is a German automobile manufacturer and part of the Volkswagen Group. The Volkswagen Group provides an update on the sustainability of the business once a year in the form of a Group sustainability report. This report outlines key strategic principles and presents examples of specific activities performed by the individual Group brands with regard to sustainability. When it comes to creating the report, they draw guidance from the internationally recognized G3 sustainability reporting guidelines provided by the Global Reporting Initiative (GRI). Certification: Level A+. Aside from financial indicators, the following social and environmental indicators are highlighted in VW's Sustainability Report: social - female employees in the Volkswagen Group, participation ratio in employee opinion survey, absenteeism, fluctuation rate, number of accidents; environmental - energy consumption, $\mathrm{CO} 2, \mathrm{NOx}, \mathrm{SO} 2$ and VOC emissions, freshwater and wastewater usage, chemical oxygen demand, waste in tonnes and expenditure on environmental protection in million euros. The overall GRI certification of Volkswagen Group is Level A+.

\section{CONCLUSION}

Companies must develop and support a broader responsibility and sustainability perspective towards their supply chains to ensure that their consumer, business, supply chain, community and environmental relationships and interactions remain viable in order to be able to face challenges for globalizing markets. 


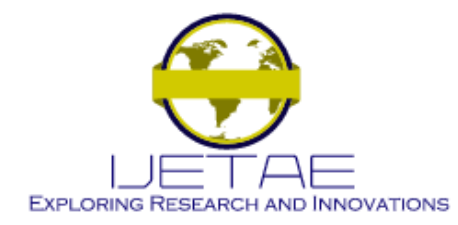

\section{International Journal of Emerging Technology and Advanced Engineering Website: www.ijetae.com (ISSN 2250-2459, ISO 9001:2008 Certified Journal, Volume 3, Issue 8, August 2013)}

Experience shows that it is a complex and long process to integrate Responsible Supply Chain Management in all levels of the organization. In this process companies are facing many challenges to overcome and it requires continuous improvement. But RSCM can provide the organization with both tangible and direct benefits, which may ultimately lead to a competitive advantage.

\section{REFERENCES}

[1] BALASUBRAMANIAN, P. \& TEWARY, A. K. (2005): Design of supply chains: Unrealistic expectations on collaboration $\mathrm{S}^{-}$adhan ${ }^{-} \mathrm{a}$ Vol. 30, Parts $2 \&$ 3, pp. 463-473.

[2 ] BALDWIN, A. - STRANDBERG, C. (2010): Canadian Business for Social Responsibility: CSR Governance Guidelines

[3 ] CARROLL, A. B. (1979). A Three Dimensional Model of Corporate Performance. Academy of Management Review, Vol. 4(4):497-505

[4] CHANDLER, G. (2001). "Defining Corporate Social Responsibility," Ethical Performance Best Practice, Fall 2002, cited in "What is Corporate Social Responsibility?" Catalyst Corporation and U.S. Agency for International Development (USAID),http://www.rhcatalyst.org/site/DocServer/CSRQ_A.pdf?\% 20docID=103 Downloaded on: September 24. 2012.

[5] CLOSS, D. J., SPEIERM C. \& MEACHAM, N. (2011): Sustainability to support end-to-end value chains: the role of supply chain management. J. of the Acad. Mark. Sci. (2011) 39:101-116 DOI 10.1007/s 11747-010-0207-4

[6] COOPER, M. C. - LAMBERT, D. M. - PAGH, J. D. (1997): Supply Chain Management: More Than a New Name for Logistics. International Journal of Logistics Management, 8(1), 1-14.

[7] CORBETT, L. M. (2009): Sustainable operations management: a typological approach. Journal of Industrial Engineering and Management. JIEM,

[8 ] $2009-2(1): 10-30$

[9] CSR Europe (2008): Leading companies launch online Portal for Responsible Supply Chain Management.

[10 ] http://www.csreurope.org/press_releases.php?action=show_press_rel ease\&press_id=28, downloaded on 24 September 2012.

[11 ] European Commission (2011): A renewed EU strategy 2011-14 for Corporate Social Responsibility.

[12 ] GLOBAL CSR and Copenhagen Business School (2011): Changing Course - A study into Responsible Supply Chain Management.

[13 ] Gold, S. (2011): Bio-energy supply chains and stakeholders. Mitig Adapt Strateg Glob Change (2011) 16:439-462. DOI $10.1007 / \mathrm{s} 11027-010-9272-8$

[14] GRI (2011): Global Action, Local Change - Moving towards Sustainable Supply Chains. https://www.globalreporting.org/resourcelibrary/Global-ActionLocal-Change.pdf, downloaded on September 24. 2012.

[15 ] HANDFIELD, R. B. - NICHOLS, E. L. (1999): Introduction to Supply Chain Management (Prentice Hall, New-Jersey). cit. Mueller, M. - Gomes dos Santos, V. - Seuring, S. (2009, p. 510.).

[16] HOPKINS, M. (2011): Definition of Corporate Social Responsibility. http://mhcinternational.com/articles/definition-of-csr Downloaded on September 24. 2012.
[17 ] HP (2011): Global Citizenship Report 2011.http://www.hp.com/hpinfo/globalcitizenship., downloaded on September 24, 2012

[18 ] HULT, G. T. M. - KETCHEN, D.J. - ARRFELT, M. (2007): Strategic Supply Chain Management: Improving Performance Through a Culture of

[19] Competitiveness and knowledge Development. Strategic Management Journal. 28: 1035-1052 (2007)

[20 ] International Chamber of Commerce (2007): ICC guidance on supply chain responsibility.

[21 ] L'Oréal (2011): Sustainable Development Report L'Oréal (2011).: www.sustainabledevelopment.loreal.com, downloaded on September 24, 2012

[22 ] LINTON, J. D., - KLASSEN, R. - JAYARAMAN, V. (2007). Sustainable supply chains: an introduction. Journal of Operations Management, 25 (6), 1075-1082.

[23 ] MENTZER J. T. - DEWITT W. - KEEBLER J. S. - MIN S. - NIX N. W. - SMITH C. D. - ZACHARIA Z.G. (2001) Defining supply chain management. Journal of Business Logistics 22 (2):1-25

[24 ] MUELLER, M. - GOMES DOS SANTOS, V. - SEURING, S. (2009): The Contribution of Environmental and Social Standards Towards Ensuring

[25] Legitimacy in Supply Chain Governance. Journal of Business Ethics (2009) 89:509-523 _ Springer 2009. DOI 10.1007/s10551-0080013-9

[26] SAM (2012): Corporate Sustainability Assessment. http://www.sustainability-indexes.com/review/annual-review2012.jsp. Downloaded: October 14, 2012

[27 ] STEURER, R., LANGER, M. E., KONRAD, A., \& MARTINUZZI, A. (2005. Corporations, stakeholders and sustainable development I: A theoretical exploration of business-society relations. Journal of Business Ethics, 61, 263-281.

[28 ] United Nations Global Compact (2010): Supply Chain Sustainability. A Practical Guide for Continuous Improvement. http://globalcompact.oit.duke.edu/globalcompact/sites/default/files/B SR\%20supply\%20chain\%20sustainability.

[29] United Nations Global Compact (2012): The Ten Principles. http://www.unglobalcompact.org/AboutTheGC/TheTenPrinciples/in dex.html. Downloaded: October 14, 2012.

[30 ] VAN OPIJNEN, M. - OLDENZIEL, J. (2011): Responsible Supply Chain Management. Potential Success Factors and Challanges for Addressing Prevailing Human Rights and Other CSR Issues in Supply Chain of EU-based Companies

[31 ] Volkswagen (2011): Nachhaltigkeitsbericht Volkswagen AG (2011): www.volkswagenag.com/nachhaltigkeit, downloaded on September 24, 2012

[32 ] WBCSD Cement Sustainability Initiative The Cement Sustainability Initiative (2011): http://csiprogress2012.org, downloaded on September 24, 2012

[33 ] WCED (1987): Our Common Future. (Oxford University Press, Oxford).

[34 ] WORTHINGTON, I. - RAM, M. - BOYAL, H. - SHAH, M. (2008): Researching the Drivers of Socially Responsible Purchasing: A Cross-National

[35 ] Study of Supplier Diversity Initiatives. Journal of Business Ethics, 179(3), 319-331. 